\title{
Effects of site, depth and sori origin on the growth and minerals composition of cultivated Saccharina latissima (Phaeophyceae) in the north of Norway
}

\author{
Xinxin Wang ${ }^{1} \cdot$ Marthe J. Blikra ${ }^{2} \cdot$ Tor H. Evensen ${ }^{1} \cdot$ Dagbjørn Skipnes $^{2} \cdot$ Philip James $^{1}$
}

Received: 15 April 2021 / Revised and accepted: 29 September 2021 / Published online: 28 October 2021

(c) The Author(s) 2021

\begin{abstract}
Interest in the cultivation of Saccharina latissima is increasing in the north of Norway. In the present study, S. latissima was cultivated at two sites (Kraknes and Rotsund), $90 \mathrm{~km}$ apart, in Troms, northern Norway $\left(69-70^{\circ} \mathrm{N}\right)$. The effect of site, depth, and sori origin (Kraknes and Rotsund) on S. latissima growth, biofouling, minerals, and potentially toxic elements (PTEs) content was studied. Large variations in the frond length and wet weight were observed between sites. The site with lower seawater temperature, higher nutrient levels and no freshwater influence (Kraknes) had better growth and later outbreak of epibionts. Sori origin had a significant effect on the growth only at the Kraknes site with S. latissima produced from the Kraknes sori having longer frond length and higher wet weight. The iodine content was, in general, high and increased with cultivation depth. The arsenic and cadmium content varied between sites and was lower than the recommended maximum level for food supplements in EU regulations. The present study shows that growth, biofouling, minerals, and PTEs content vary profoundly within the same geographical region and between sori origin, it thereby underlines the importance of site selection and using traits with high growth rates for seeding and cultivation to achieve maximum biomass.
\end{abstract}

Keywords Saccharina latissima $\cdot$ Translocation $\cdot$ Growth $\cdot$ Minerals $\cdot$ Potentially toxic elements $\cdot$ Seaweed cultivation

\section{Introduction}

The aquaculture of various seaweed species makes up more than half of the total worldwide production of marine aquaculture (FAO 2020). Recently, seaweed farming has expanded to European countries, with Saccharina latissima (Linnaeus) Lane, Mayes, Druehl and Saunders being the most important commercially cultivated species due to its broad geographical distribution, high growth rate, wellknown life cycle, easy cultivation protocols, and various application possibilities (Müller et al. 2009; Araújo et al. 2021).

In Norway, as in many parts of Europe, S. latissima cultivation is a relatively new industry. Currently, almost all of the $S$. latissima grown in Norway is produced in the south or middle latitudes (Skaar 2019; Forbord 2020), but there is
Xinxin Wang
xinxin.wang@nofima.no
Nofima AS, P.O. Box 6122, NO-9291 Troms $\varnothing$, Norway
2 Nofima AS, P.O. Box 8034, NO-4068 Stavanger, Norway

potential for seaweed cultivation along the entire latitudinal gradient from 58 to $71^{\circ} \mathrm{N}$ (Matsson et al. 2019). It has been suggested that by 2050, the value of the seaweed industry may reach 4 billion Euro per year in Norway, with a production of 20 million tonnes per year (Olafsen et al. 2012; Broch et al. 2019).

To cultivate $S$. latissima efficiently, understanding the physical and biological factors that affect survival and growth and developing appropriate production strategies will be among the keys to success. For example, the growth of S. latissima adult sporophytes have been found to be light-saturated at $70 \mu \mathrm{mol}$ photons $\mathrm{m}^{-2} \mathrm{~s}^{-1}$ and showed photoinhibition at $250 \mu \mathrm{mol}$ photons $\mathrm{m}^{-2} \mathrm{~s}^{-1}$ (Fortes and Lüning 1980; Han and Kain 1996; Forbord 2020; Jevne et al. 2020). Regarding nutrients, the growth of S. latissima is often nitrogen limited (Bruhn et al. 2016) with saturation around $10 \mu \mathrm{M}$ nitrate (Chapman et al. 1978), even though phosphorus limitation is also observed in eutrophic areas (Pedersen et al. 2010). Saccharina latissima is well adapted to oceanic salinity and grows optimally between 30 and 35 psu (Kerrison et al. 2015). Temperature is another key variable affecting the growth of S. latissima and the optimal 
temperature for growth ranges from 10 to $15{ }^{\circ} \mathrm{C}$, with a decrease in growth below $5{ }^{\circ} \mathrm{C}$ and high mortality being reported at and above $20^{\circ} \mathrm{C}$ (Andersen et al. 2013). Another factor affecting the growth and quality of $S$. latissima is biofouling. Epibionts growing on the fronds of S. latissima can form a barrier inhibiting nutrient absorption (Hurd 2000) and light availability (Andersen et al. 2013) and may cause loss of biomass through increased drag and friction and decreased flexibility (Krumhansl et al. 2011). To ensure high quality while at the same time avoiding biomass loss, S. latissima is usually harvested in spring or early summer in the southern and central parts of Norway. However, in the north, the outbreak of epiphytic organisms is delayed compared to more southern sites, allowing for prolonged harvesting. In addition, the combined benefits of $24 \mathrm{~h}$ of sunlight and low sea temperature during the summer season suggest that there is great potential for S. latissima cultivation in the north (Matsson et al. 2019).

Saccharina latissima has a relatively high mineral content, where the most important components are sodium, potassium, calcium, and magnesium, followed by iodine and phosphorus. The tolerable daily dose of iodine reported by the European Food Safety Authority (EFSA) is $0.6 \mathrm{mg}$ (EFSA 2014), and farmed S. latissima has been recorded with 1556-7208 $\mathrm{mg} \mathrm{kg}^{-1}$ dry weight (dw) depending on the cultivation sites (Lüning and Mortensen 2015; Roleda et al. 2018; Sharma et al. 2018). Saccharina latissima used as food and feed ingredients could therefore lead to excessive iodine consumption if the high iodine content is not controlled. However, the iodine content can be reduced by $38-94 \%$ by post-harvest processing such as blanching, boiling and fermentation (Lüning and Mortensen 2015; Bruhn et al. 2019; Nielsen et al. 2020; Blikra et al. 2021). Potentially toxic elements (arsenic, cadmium, lead, and mercury) have been found to accumulate in cultivated S. latissima, again depending on cultivation site and season (Bak 2019; Roleda et al. 2019; Duinker et al. 2020).

Currently, sori materials for sporeling production of $S$. latissima are typically collected from local genotypes to minimize the risk of genetic transfer between geographic regions. However, the environmental conditions (i.e., temperature, light, nutrients, silinity) vary between sites even within a regional scale, and this may result in different parental phenotypes which can greatly modify the growth of the offspring. This was well documented in terrestrial plants (Baker et al. 2019, and references therein), and may also be applicable for S. latissima. Thus, sori materials collected from the same region may have different phenotypes, which could affect the growth and chemical composition of the final biomass.

The overall objective of this study is to investigate the effect of site, depth, and the origin of sori on the frond length, weight, minerals, and potentially toxic elements (PTEs) content of cultivated S. latissima in northern Norway. Our hypothesis is that sites have significant effect on the growth, timing of epibionts, minerals, and PTEs content of cultivated S. latissima even within the same geographic region. We also hypothesize that S. latissima have different growth rates within the same geographic region depending on the environmental conditions.

\section{Materials and methods}

\section{Sporeling production}

Saccharina latissima sporophytes were collected from two different locations: Kraknes and Rotsund (Fig. 1) in January 2020 and were brought back to the seaweed laboratory at Nofima Troms $\varnothing$. For each site, ripe sori tissues from 10 to 15 sporophytes were cut out and used for production of sporeling lines. The Rotsund sori had darker color, harder tissues, and were bumpier than the Kraknes sori. Sporelings were produced at the Nofima seaweed hatchery in Troms $\varnothing$, with minor revision from Forbord et al. (2018). A solution of about 250,000 spores $\mathrm{mL}^{-1}$ seawater was brushed onto 1.2-mm-diameter twine coiled around PVC spools. The spools were then incubated for 8-10 weeks in seawater in two flow-through $\left(120 \mathrm{~L} \mathrm{~h}^{-1}\right)$ cylinders $(150 \mathrm{~cm}$ high and $50 \mathrm{~cm}$ diameter) in a temperature-controlled room at $10^{\circ} \mathrm{C}$. LED lights were placed both in and outside the cylinders, the light intensity was set at $20 \mu \mathrm{mol}$ photons $\mathrm{m}^{-2} \mathrm{~s}^{-1}$ initially
Fig. 1 Overview of hatchery and cultivation site (Kraknes and Rotsund)

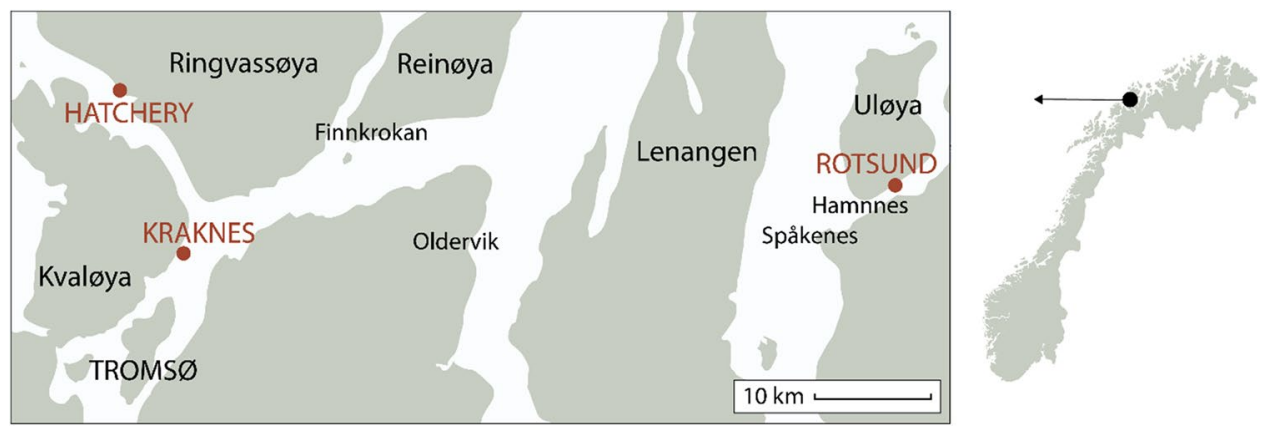


and increased to $70 \mu \mathrm{mol}$ photons $\mathrm{m}^{-2} \mathrm{~s}^{-1}$ towards the end of the incubation period. Seawater temperatures were kept at about $10^{\circ} \mathrm{C}$ in the first 6 weeks and then gradually decreased to ambient seawater temperature.

\section{Cultivation sites}

When the sporelings reached an average length of approximately $0.5 \mathrm{~cm}$, the $1.2-\mathrm{mm}$ twines containing the sporelings were entwined onto $10-\mathrm{m}$ long, 10-mm-thick ropes and packed in polystyrene boxes. Five ropes from each sori origin were shipped back to the sea sites where the sori were collected and another 5 ropes from each sori origin were translocated to Kraknes and Rotsund respectively (Fig. 1). At each site, 10 sporeling lines ( 5 from each sori origin) were randomly selected and uniformly deployed along a longline approximately $2 \mathrm{~m}$ from one another. Each line was attached to the longline with a $1-\mathrm{kg}$ weight attached at the bottom so that it would hang vertically.

Sporelings were deployed in February at Rotsund and in March at Kraknes (Fig. 1). The Rotsund site is a commercial cultivation site run by Lyngsskjellan AS, it is located on the south side of the island Uløya $\left(69^{\circ} 47^{\prime} 30.3^{\prime \prime} \mathrm{N} 20^{\circ} 36^{\prime}\right.$ $01.9^{\prime \prime} \mathrm{E}$ ) in Lyngen. This site is sheltered with main current direction towards the west and water depth of $15-35 \mathrm{~m}$. The site is relatively close to a mussel farm and a salmon farm ( $2 \mathrm{~km}$ east). Previously, the current velocity was measured by Lyngsskjellan AS at $5 \mathrm{~m}$ depth from May to June 2010, with an average value of $6.6 \mathrm{~cm} \mathrm{~s}^{-1}$, and a maximum value of $49 \mathrm{~cm} \mathrm{~s}^{-1}$.

The Kraknes site is a research site, run by AkvaplanNiva. The site is located on the island of Kvaløya $\left(69^{\circ}\right.$ $45.259 \mathrm{~N} / 019^{\circ} 02.176 \mathrm{E}$ ) near Troms $\varnothing$, with a water depth of 15-20 m. This site has well-mixed water masses through tidal currents. The main current direction was towards the northwest. Previously, the current velocity was measured over 120 days at $12 \mathrm{~m}$ depth from March to July 2011, with an average of $3.4 \mathrm{~cm} \mathrm{~s}^{-1}$, and a maximum of $22 \mathrm{~cm} \mathrm{~s}^{-1}$ (Matsson et al. 2019).

\section{Monitoring of growth and environmental factors}

The length and wet weight of $S$. latissima sporophytes at both sites from 0-2-, 5-7-, and 8-10-m depth intervals were monitored approximately once a month during the growth period. At each sampling day, 10 individual S. latissima sporophytes from each rope and each depth interval were sampled and brought back to the lab for length and wet weight analysis (drip losses were not included). Thereafter, samples were stored at $-30{ }^{\circ} \mathrm{C}$ until further analyses.

The light intensity (lux) and temperature $\left({ }^{\circ} \mathrm{C}\right)$ were monitored every 15 min using Onset HOBO pendant loggers (Bourne, USA; temperature accuracy $\pm 0.53{ }^{\circ} \mathrm{C}$, resolution
$0.14{ }^{\circ} \mathrm{C}$ ) at 2-, 6-, and 10-m depths respectively. The lux measurements were converted to photosynthetically active radiation (PAR) according to Broch et al. (2013). The loggers were cleaned each sampling day (approximately once per month). There was no S. latissima growing on the sensor ropes to avoid any shading effect.

Seawater samples for dissolved inorganic nitrogen (DIN) and phosphorus (DIP) concentration measurements were collected at 2, 6, and $10 \mathrm{~m}$ depth with a Ruttner water sampler and analyzed with an autoanalyzer (Flow Solution IV System, I.O. Analytical) according to the Norwegian Standard 4745 .

\section{Biofouling}

The percentage of epibiont coverage on the frond was estimated for samples harvested in June at Rotsund and in August at Kraknes, using the protocol described by Matsson et al. (2019). For samples collected at both Rotsund and Kraknes sites, images were taken from four sporophytes from each depth and each sori origin. The sporophytes were placed on a large white paper and gently smoothed out the blades. Grids with $1 \mathrm{~cm}^{2}$ per point were added to the images by the free software ImageJ (Fig. 2). The total points of the frond $\left(N_{F}\right)$ and the points both fully and partially covered by epibionts $\left(N_{E}\right)$ were then counted. The total area of the frond $\left(S_{F}\right)$ was calculated as $N_{F} \times 1 \mathrm{~cm}^{2}$. The area coved by epibionts $\left(S_{E}\right)$ was calculated as $\mathrm{N}_{\mathrm{E}} \times 1 \mathrm{~cm}^{2}$. The percentage of epibionts cover was calculated using the following formula:

$\left(S_{E} / S_{F}\right) \times 100$

\section{Minerals analyses}

The samples of S. latissima sporophytes were thawed at room temperature and dried at $25^{\circ} \mathrm{C}$ for $72 \mathrm{~h}$, before grinding to a fine powder with a grinding mill. To obtain enough dry material for minerals analyses, samples $(n=30)$ from the same sample (site, depth, sori origin, and sampling date respectively) were pooled together and stored in a dark at room temperature until further analyses. Mineral content was analyzed for samples collected in late June from all three depth intervals, both sori and both cultivation sites (Kraknes and Rosund).

Analyses of calcium, potassium, magnesium, sodium, and phosphorus were performed by Celignis Biomass Laboratory, Limerick, Ireland. All elements were determined using Agilent 5110 ICP-OES. The lower limit of detection was $1 \mathrm{ppm}$. Analysis of arsenic, cadmium, lead, and mercury was performed by ALS Scandinavia AB Luleå Aurorum 10, Sweden, following SS-EN 13,805:2014 and using accredited methodology, as described by Blikra et al. (2021). Elemental 
Fig. 2 Example of image analysis used to estimate the percentage of epibionts coverage of S. latissima frond harvested in late June. Grids with $1 \mathrm{~cm}^{-2}$ per point were added to the images by the free software ImageJ

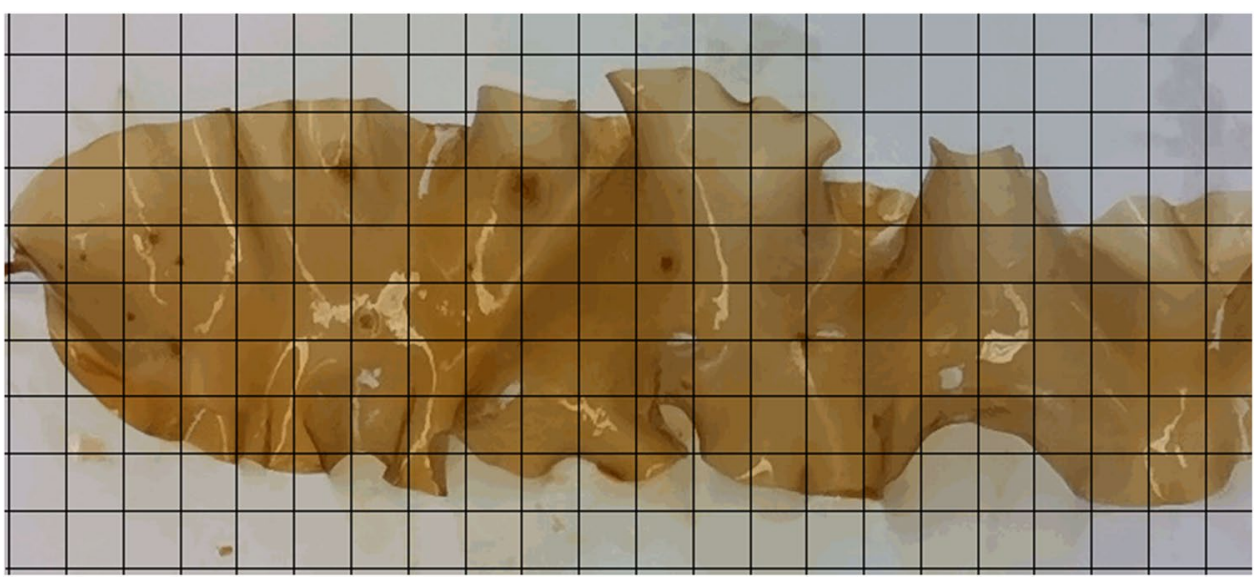

iodine analyses were performed by Mikroanalytisches Labor Kolbe, Oberhausen, Germany. Ground seaweed samples $(n=3)$ were crushed using an IKA MF10 mill and taken through a $0.5-\mathrm{mm}$ sieve. The digestion was done in a special combustion unit from A1-Envirosciences (AQF-2100) with a manual sampler, at $1100{ }^{\circ} \mathrm{C}$, and burned in an argon/ oxygen stream. The resulting gases were measured on a Metrohm Model 883 Plus ion chromatograph. The lower limit of detection was $1 \mathrm{ppm}$.

\section{Statistical analyses}

The frond length, wet weight, and mineral content were presented as mean ( \pm standard error). The differences in frond length and wet weight between site, depth, sori origin, and sampling date were tested using a four-way ANOVA followed by Tukey's multiple comparison tests when more than two sample groups were present. The differences in frond length and wet weight between sori origin, depth, and sampling date for each site were tested using a threeway ANOVA followed by Tukey's multiple comparison tests when more than two sample groups were present. The significance limit was set to 0.05 . All tables were made in Microsoft Excel and graphs were prepared in SIGMA PLOT 14.0(Systat Software Inc) and free software R, version 3.6.0 through R Studio.

\section{Results}

\section{Environmental factors}

At Kraknes the salinity was stable between 31.3 and 32.8 psu at all three depths from March to August, whereas at Rotsund it varied between depths from 25.0 to 33.8 psu during the growth period (Fig. 3A). At a 2-m depth, the salinity at Rotsund was below 30 psu from March to August.
Generally, the average daily seawater temperature increased slowly from March to May at both sites and all depths until June, then increased rapidly through to August (Fig. 3B). The highest daily seawater temperature was found at $2 \mathrm{~m}$ at Rotsund $\left(14.3^{\circ} \mathrm{C}\right)$ which was $5^{\circ} \mathrm{C}$ higher than the highest value found at Kraknes $\left(9.3^{\circ} \mathrm{C}\right)$. The difference in daily seawater temperature between depths was greater at Rotsund than at Kraknes (Fig. 3B).

The general trend for daily accumulated photosynthetically active radiation (PAR) increased from March to May and June then decreased in August (Fig. 3C). The highest value was found at $2 \mathrm{~m}$ at Kraknes. The daily accumulated PAR at $8 \mathrm{~m}$ for both sites was generally quite low except in late June-July. At the Rotsund site, which was influenced by freshwater, PAR was lower than at the Kraknes site.

The dissolved inorganic nitrogen (DIN) concentrations dropped rapidly from March to May, coinciding with the spring bloom. Generally, the DIN values at the Kraknes site were higher than at the Rotsund site during the experimental period (Supplementary Material Fig. 6A). The same trend was found for dissolved inorganic phosphorus concentrations (DIP) as DIN concentrations (Supplementary Material Fig. 6B).

\section{Growth}

Generally, the frond length of S. latissima increased from March to June and August at Rotsund and Kraknes, respectively (Fig. 4A-D). After this time, the frond length decreased due to the heavy biofouling. The wet weight increased from March to August and September at Rotsund and Kraknes, respectively. Cultivation site, depth, and sori origin all had significant effects on the final frond length and wet weight (Table 1).

The longest average fronds were obtained from Kraknes sori cultivated at Kraknes at 8-10 m depth and harvested in August, with an average length of $168 \pm 8 \mathrm{~cm}$. The frond length of $S$. latissima cultivated at $0-2$ and 5-7 $\mathrm{m}$ at 


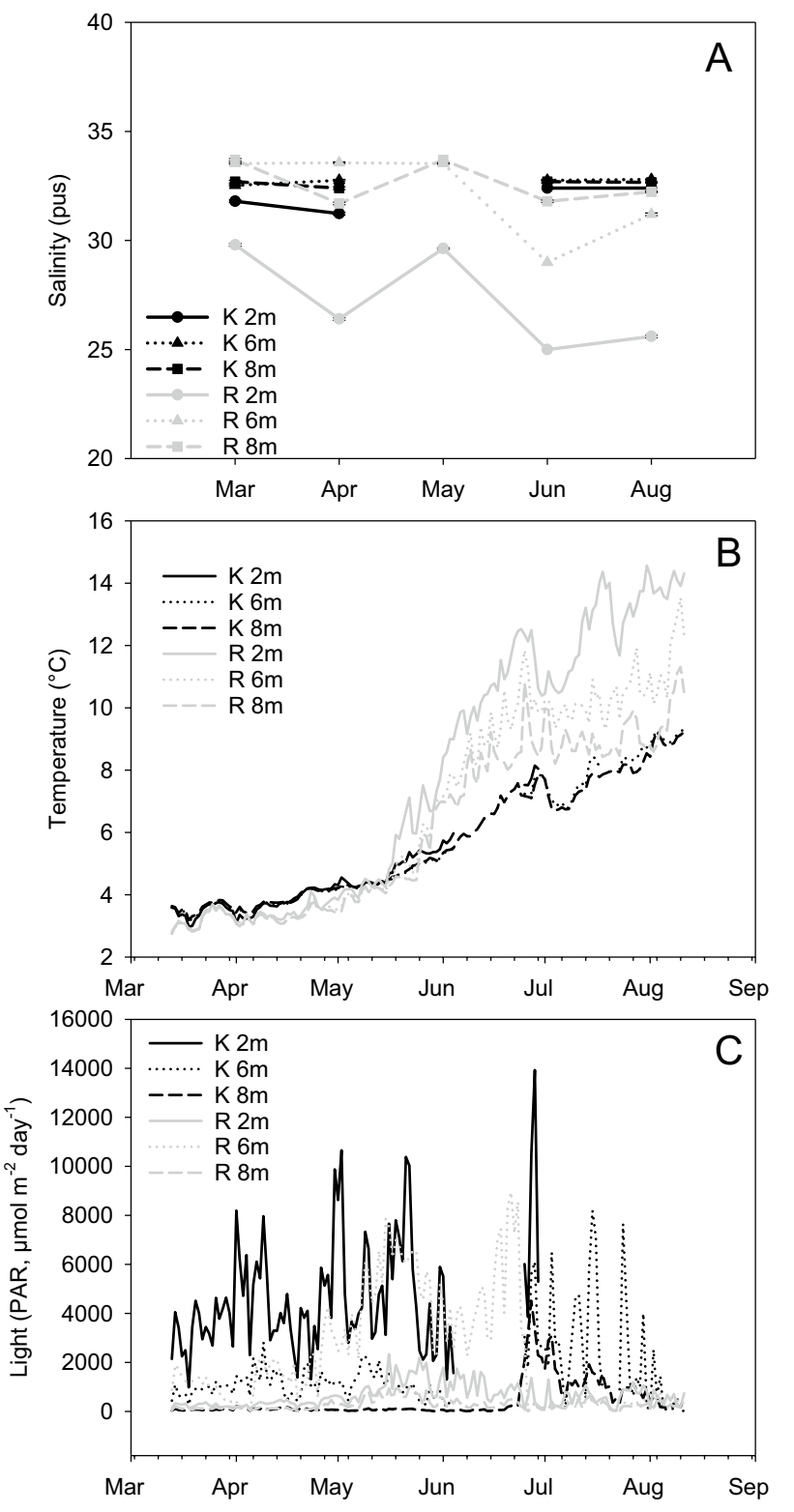

Fig. 3 A Average salinity (psu), B daily average water temperature $\left({ }^{\circ} \mathrm{C}\right)$ and $\mathbf{C}$ Photosynthetically active radiation (PAR, $\mu$ mol photons $\mathrm{m}^{-2}$ day $^{-1}$ ) measured at 2, 6, and $8 \mathrm{~m}$ depth at the Kraknes and Rotsund sites

the same site were $158 \pm 5$ and $145 \pm 10 \mathrm{~cm}$, respectively (Fig. 4A). The frond length of Rotsund sori cultivated at Kraknes was about half of the Kraknes sori, with a length of $86 \pm 2,82 \pm 2$, and $76 \pm 3$ at $0-2,5-7$, and $8-10 \mathrm{~m}$, respectively. The same trend was found in wet weight as in frond length, with higher value from Kraknes sori cultivated at Kraknes at 8-10 m (244 $\pm 26 \mathrm{~g})$, compared to 0-2 and 5-7 m (176 \pm 13 and $209 \pm 27 \mathrm{~g}$, respectively). The wet weight from Rotsund sori cultivated at Kraknes was $45 \pm 2.3,54 \pm 3.5$, and $51 \pm 3.2 \mathrm{~g}$ for $0-2-, 5-7-$, and 8-10-m intervals, respectively (Fig. 4C).
At Rotsund, the average frond length and wet weight across both sori origins was in the range of 54-67 cm (Fig. 4B) and 8.4-18 g (Fig. 4D), respectively. No significant differences were found in frond length $(p=0.60)$ and wet weight $(p=0.22)$ between sori origin. At the Rotsund site, the average length and wet weight of S. latsissima were significantly lower than at the Kraknes site (Table 1).

At Kraknes, there were no epibionts on the fronds between March and late June (no samples were taken in July). The epibionts were observed in the middle of August mainly on the distal part of the frond. The fouling was then dominated by filamentous brown algae, with an average fouling coverage of $7.0-20 \%$ (Table 2). No significant differences were found between sori origin and depth $(p>0.05)$. In September, S. latissima fronds were fully covered by bryozoans, filamentous brown algae, and hydroids.

At Rotsund, fouling occurred much earlier than at the Kraknes site. The biofouling was found mainly on the meristem part of S. latissima in June and further developed with the whole blade covered by bryozoan in the middle of August. The average epibionts coverage was in the range of $6.8-7.4 \%$ and $2.8-8.7 \%$ for Kraknes sori and Rotsund sori, respectively (Table 2 ), and were significantly different between sori origin and depth $(p<0.05)$.

\section{Major elements}

Among the minerals analyzed in the present study, potassium $\left(64,781-19,510 \mathrm{mg} \mathrm{kg}^{-1} \mathrm{dw}\right)$ was the most abundant in the cultivated $S$. latissima followed by sodium (28,314-54,777 mg kg${ }^{-1} \mathrm{dw}$ ), calcium (9343-16,659 $\mathrm{m} \mathrm{kg}^{-1}$ $\mathrm{dw}$ ), magnesium (6270-10,631 mg kg${ }^{-1} \mathrm{dw}$ ), and phosphorus (1343-4895 mg kg-1 dw) (Table 3). The average potassium and sodium content were $45 \%$ and $10 \%$, respectively higher at the Kraknes site than at the Rotsund site. The average calcium and magnesium were $21 \%$ and $6.5 \%$, respectively lower at the Kraknes site than at the Rotsund site. The phosphorus content showed positive correlation with increasing cultivation depth and was $40 \%$ higher at the Kraknes site than at the Rotsund site (Table 3).

\section{lodine content}

The iodine content was in the range of $2100-7933 \mathrm{mg} \mathrm{kg}^{-1}$ $\mathrm{dw}$ and the highest value was found at Rotsund cultivated at 8-10 m depth from Rotsund sori (Table 3). For both sites, the iodine content increased with cultivation depth. The average iodine content was $20 \%$ higher at the Rotsund site than at the Kraknes site. Saccharina latissima from the Kraknes sori contained less iodine content than the Rotsund sori, irrespective of cultivation sites. 
Fig. 4 Frond length $(\mathrm{cm})$ and wet weight $(\mathrm{g})$ of cultivated $S$. latissima from two different sori origin at three depth intervals $(0-2,6-7$, and $8-10 \mathrm{~m})$ at both sites. Mean \pm SE. $n>30$. A Frond length at Kraknes site (K) from Kraknes sori (k) and Rotsund sori (r). B Frond length at Rotsund site (R) from Kraknes sori (k) and Rotsund sori (r). C Wet weight at Kraknes site (K) from Kraknes sori (k) and Rotsund sori (r). D Wet weight at Rotsund site (R) from Kraknes sori (k) and Rotsund sori (r)

Table 1 Results of the statistical analysis of the effect of site, depth, origin of sori and sampling date, and their interaction on the length and wet weight of $S$. latissima at the Kraknes and Rotsund sites
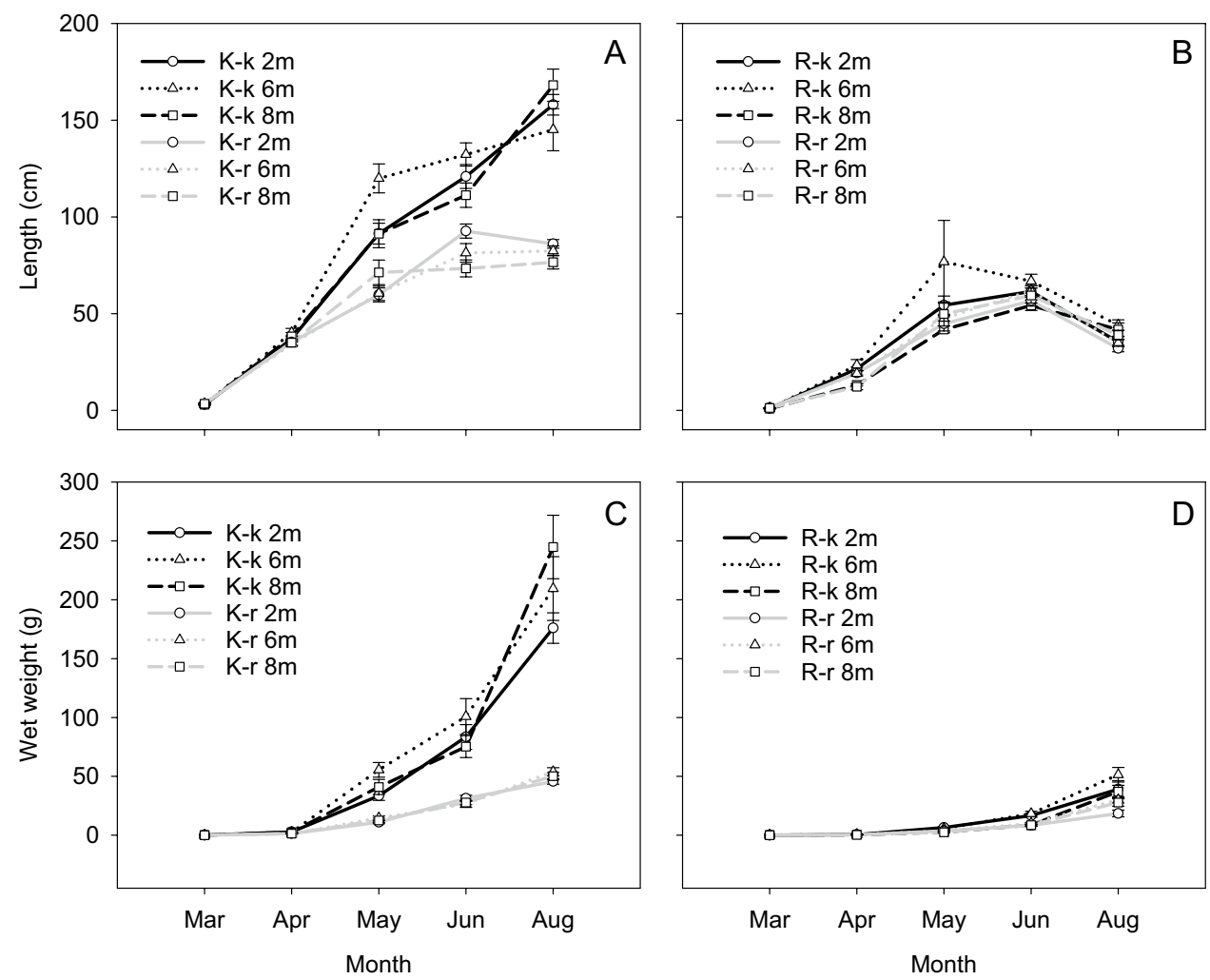

\begin{tabular}{|c|c|c|c|c|c|c|}
\hline \multirow[t]{3}{*}{ Effect } & \multicolumn{6}{|c|}{ Variable } \\
\hline & \multicolumn{3}{|c|}{ Length } & \multicolumn{3}{|c|}{ Weight } \\
\hline & $D f$ & $F$ & $P$ & $D f$ & $F$ & $P$ \\
\hline Site & 1 & 542.4417 & $<0.001$ & 1 & 436.2996 & $<0.001$ \\
\hline Sori & 1 & 111.1136 & $<0.001$ & 1 & 199.9587 & $<0.001$ \\
\hline Date & 4 & 533.2986 & $<0.001$ & 4 & 453.1749 & $<0.001$ \\
\hline Depth & 2 & 16.60548 & $<0.001$ & 2 & 15.44255 & $<0.001$ \\
\hline Site:sori & 1 & 65.47512 & $<0.001$ & 1 & 163.0182 & $<0.001$ \\
\hline Site:date & 4 & 96.25972 & $<0.001$ & 4 & 113.2229 & $<0.001$ \\
\hline Sori:date & 4 & 33.66264 & $<0.001$ & 4 & 117.3511 & $<0.001$ \\
\hline Site:depth & 2 & 1.857527 & 0.1564 & 2 & 14.30579 & $<0.001$ \\
\hline Sori:depth & 2 & 4.578647 & 0.0104 & 2 & 13.39357 & $<0.001$ \\
\hline Month:depth & 8 & 3.211713 & 0.0013 & 8 & 8.394745 & $<0.001$ \\
\hline Site:sori:date & 4 & 24.02095 & $<0.001$ & 4 & 68.71628 & $<0.001$ \\
\hline Site:sori:depth & 2 & 2.320055 & 0.0986 & 2 & 23.39623 & $<0.001$ \\
\hline Site:date:depth & 8 & 1.035131 & 0.4071 & 8 & 4.777454 & $<0.001$ \\
\hline Sori:date:depth & 8 & 2.262594 & 0.0210 & 8 & 7.26112 & $<0.001$ \\
\hline Site:sori:date:depth & 7 & 0.850909 & 0.5451 & 7 & 8.137097 & $<0.001$ \\
\hline
\end{tabular}

\section{Potentially toxic elements}

The average contents of arsenic and cadmium were in the range of $32-76 \mathrm{mg} \mathrm{kg}^{-1} \mathrm{dw}$ and $0.63-2.15 \mathrm{mg} \mathrm{kg}^{-1}$ $\mathrm{dw}$, respectively. The lead and mercury contents were generally low, in the range of $0.288-1.21 \mathrm{mg} \mathrm{kg}^{-1} \mathrm{dw}$ and $0.0225-0.0408 \mathrm{mg} \mathrm{kg}^{-1} \mathrm{dw}$ during the growth period, respectively (Table 3 ).

In June, the arsenic and cadmium content of S. latissima were different between sites, with $52 \%$ lower values for the 
Table 2 Percentage of epibionts coverage (\%) in S. latissima frond harvested from three depth intervals and two sori origins in June at the Rotsund site and in August at the Kraknes site

\begin{tabular}{lllll}
\hline \multicolumn{4}{l}{ Epibionts coverage (\%) } & \multicolumn{3}{l}{} \\
\hline Site & Sori origin & \multicolumn{2}{l}{ Depth $(\mathrm{m})$} & \\
\cline { 3 - 5 } & & $0-2$ & $5-7$ & $8-10$ \\
\hline Rotsund & Kraknes & $7.5 \pm 1.7$ & $6.8 \pm 1.0$ & $7.5 \pm 0.3$ \\
& Rotsund & $1.1 \pm 0.2$ & $2.8 \pm 0.9$ & $8.7 \pm 0.3$ \\
Kraknes & Rotsund & $16 \pm 2.4$ & $20 \pm 1.8$ & $14 \pm 2.0$ \\
& Kraknes & $7.0 \pm 3.5$ & $14 \pm 5.4$ & $15 \pm 2.9$ \\
\hline
\end{tabular}

specimen cultivated at the Rotsund site. Both arsenic and cadmium content increased with depth. The arsenic content was slightly different between sori origins, while no differences were found in the cadmium content (Table 3).

\section{Discussion}

\section{Growth}

The maximum average frond length of S. latissima $(168 \pm 8.3 \mathrm{~cm})$ in the present study from the Kraknes site was longer than the frond length found in previous studies investigating S. latissima cultivation in Norway $(15-136 \mathrm{~cm})$ (Wang et al. 2014; Matsson et al. 2019; Forbord et al. 2020a, b), across Europe (Peteiro et al. 2014; Rolin et al. 2017; Bak et al. 2018), and America (Augyte et al. 2017; Grebe et al. 2019). This suggests that $S$. latissima production is promising in the north of Norway (Matsson et al. 2019; Forbord et al. 2020a). However, the data show that the cultivation site had the strongest effect on the growth of cultivated S. latissima when compared to cultivation depth and sori origin (Fig. 5). The average length and wet weight of S. latissima harvested in August at Kraknes were significantly longer and higher than those harvested in June at Rotsund (Table 1 and Fig. 4), supporting the importance of site selection for successful growth of kelp, even within the same geographical region.

Saccharina latissima sporophytes are tolerant to a broad range of temperatures and the optimal temperature varies with and within the geographic range (Fortes and Lüning 1980; Davison et al. 1991; Andersen et al. 2013). The optimal temperature for $S$. latissima from southern Norway was found between 10 and $15{ }^{\circ} \mathrm{C}$ and sporophytes showed poorer performance and relatively high mortality when exposed to $20{ }^{\circ} \mathrm{C}$ for 3-4 weeks (Andersen et al. 2013). In the current study, at the Kraknes site, the seawater temperature never exceeded $10{ }^{\circ} \mathrm{C}$. Saccharina latissima cultivated at this site had significantly longer frond length and higher wet weight. At the Rotsund site where the water temperature increased from

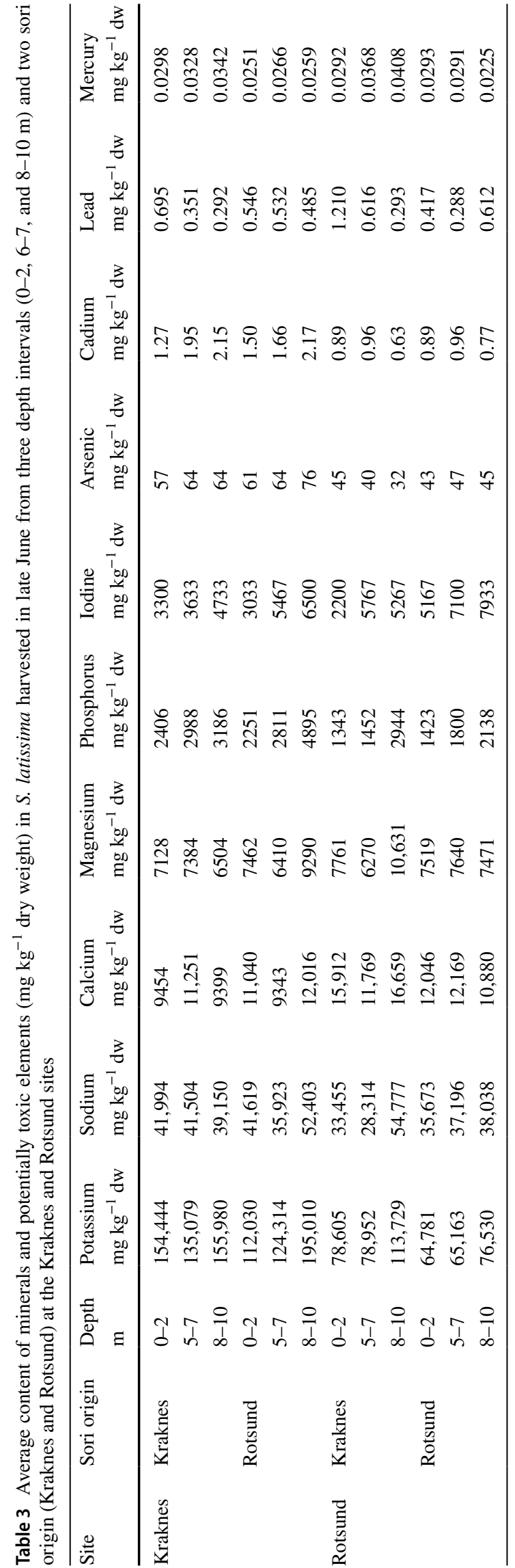


Fig. 5 Principal component analysis of length, wet weight, light, temperature and mineral content of S. latissima harvested in June: A at two cultivation sites (Kraknes and Rutsund); $\mathbf{B}$ cultivated at $0-2$, 5-7 and 8-10 $\mathrm{m}$ depth intervals; $\mathbf{C}$ from two sori origin (Kraknes and Rotsund). Numbers at the $x$ (PC-1) and $y$-axis (PC-2) are the percentages of variance in length, wet weight, light, temperature, and mineral content explained by principal components 1 and 2

$10{ }^{\circ} \mathrm{C}$ in June to $14{ }^{\circ} \mathrm{C}$ in August, S. latissima sporophytes had poorer growth. In addition, samples from Rotsund were paler and appeared bleached. This latter observation was also reported by Andersen et al. (2013), who found that the pigment concentration of S. latissima grown in the south of Norway decreased slightly as the growth temperature raised from 10 to $15^{\circ} \mathrm{C}$. In addition, our results suggest that increased seawater temperature had a negative effect on the length and wet weight of S. latissima (Fig. 5) and the optimal temperature for S. latissima originating from northern Norway may be below $10^{\circ} \mathrm{C}$. The authors suggest that further studies are required to describe the optimal growing temperatures for S. latissima grown in northern Norway.

The growth of cultivated S. latissima showed positive correlation with salinity (Fig. 5). At the Kraknes site, the salinity was relatively high and stable during the growth period. The salinity at the Rotsund site was below $30 \mathrm{psu}$ (at $2 \mathrm{~m}$ ) and had seasonal fluctuations due to the freshwater run-off from the Rotsund river. The lower salinity at the Rotsund site was correlated with lower growth rate $(50 \%$ and $90 \%$ reduction in length and weight, respectively) than the Kraknes site. Similarly, during a cultivation experiment comparing growth of $S$. latissima at different sites further south along the Norwegian coast, the frond length and maximum yield of $S$. latissima were low at all freshwaterinfluenced sites (Forbord et al. 2020a). A reduction of 22\% in growth at a salinity of 21 psu compared to the growth at 33 psu for juvenile $S$. latissima has also been reported in the NW Atlantic (Gerard et al. 1987). The growth of S. latissima was also reduced at freshwater-influenced sites in Danish water (Bruhn et al. 2016; Boderskov et al. 2021). Therefore, our results support the theory of Kerrison et al. (2015), who recommended that the salinity for $S$. latissima cultivation should be in the range of 30-35 psu and should not suffer from significant seasonal or sporadic reductions below this.

PAR also had a positive effect on the growth of $S$. latissima. A significant decrease in length was found in April, June, and August for kelp cultivated at 8-10 m compared to kelp cultivated at 0-2- and 5-7-m depth. This decrease was probably caused by light limitation in these months, either due to the low PAR in April or light shading from the proximal sporophytes in June and August.

DIN and DIP concentrations fluctuated with month, decreased rapidly from March to May. Saccharina latissima maintain their growth by accumulating excess nutrients during winter to sustain the growth during summer, when

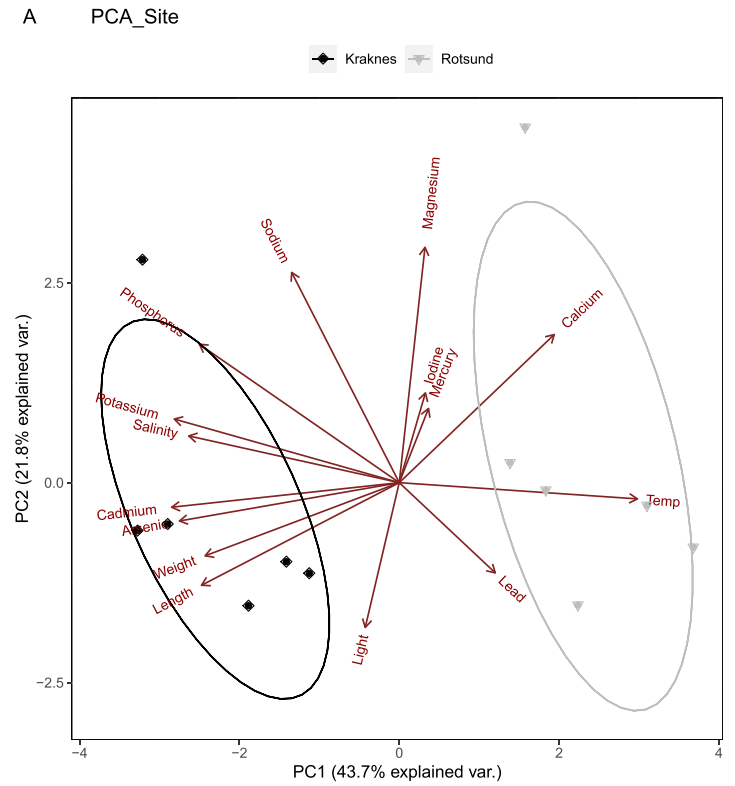

B PCA_depth
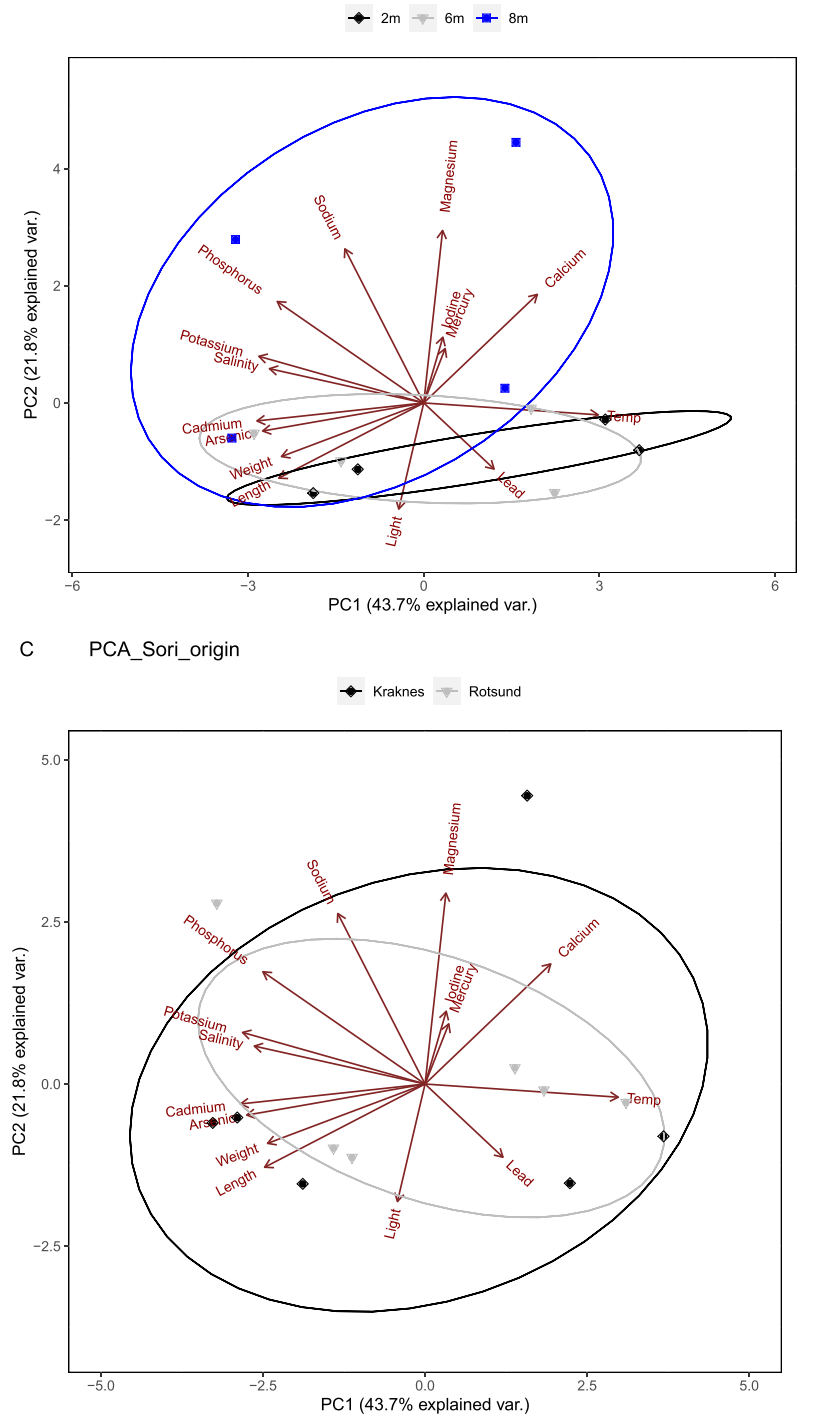
nutrients are limited (Young et al. 2009). Such nutrient reserves can also increase the tolerance to high temperatures and low salinities, such as though experienced at the Rotsund site (Kim et al. 2015). In the present study, the DIN and DIP concentrations varied between the two cultivation sites. The higher DIN concentrations found at the Kraknes site correlated with significantly longer frond length and higher wet weight. Therefore, the present study suggests the Kraknes site is more suitable for S. latissima cultivation.

There were no significant differences in length between the 0-2- and 5-7-m depth intervals in the present study. The average length of $S$. latissima across two sites at $8-10 \mathrm{~m}$ were only 5-9\% shorter than at 0-2 m, suggesting that cultivating $S$. latissima on vertical lines from the surface down to $10 \mathrm{~m}$ would be suitable in northern Norway. This was also demonstrated by Bak et al. (2018) in Faroe Islands, who suggested that the optimal cultivation was using $10 \mathrm{~m}$ growth lines and the Ocean Rain Forest designed Macroalgae Cultivation Rig.

The sori origin had a significant effect on the growth at the Kraknes site. Morphological differences were found between the two sori origins which were collected from locations $90 \mathrm{~km}$ apart from each other. Those morphological differences, as well as differences in growth under certain conditions, were also found in S. latissima from Northern and Southern Norway (Futsæter and Rueness 1985). The environmental conditions (i.e., temperature, light, nutrients, silinity) varied between sites, and this may result in different parental phenotypes and genetics which can greatly modify the growth of the offspring (Baker et al. 2019, and references therein). The authors belive that the longer frond length and greater wet weight of $S$. latissima from the Kraknes sori compared to the Rotsund sori are most likely due to the inherent genetic differences caused by the variations in the environmental conditions. This cannot be confirmed without the genetic and phenotypic features of the mother plants and should be investigated in future studies. This reveals the importance of selecting suitable traits for S. latissima production.

At Kraknes, S. latissima sporophytes harvested in late June were pristine without any biofouling. However, on the samples harvested in middle August, biofouling had started to appear. It is not clear when the first epibionts appeared as we did not collect samples in July. In the southwest coast and central Norway, epibionts on cultivated S. latissima were first recorded in late March and mid-June and a large part of the blades were lost in the end of August (Lüning and Mortensen 2015; Førde et al. 2016; Skaar 2019). To restrict biofouling S. latissima is harvested in April-May in southern and central parts of Norway (Skaar 2019; Forbord 2020). Our results showed a prolonged growing and harvesting season through to late June-July at the Kraknes site. Therefore, producers can take the advantage of $24 \mathrm{~h}$ of light in the fast-growing summer season. However, in contrast the epibionts at the Rotsund site were observed in late June, which is earlier than at the Kraknes site. This may be caused by the elevated seawater temperature at the Rotsund site, which increased from $10{ }^{\circ} \mathrm{C}$ in June to $14{ }^{\circ} \mathrm{C}$ in August, while the seawater temperature never exceeded $10{ }^{\circ} \mathrm{C}$ at the Kraknes site. Saunders et al. (2010) predicted that an increase of $1^{\circ} \mathrm{C}$ and $2{ }^{\circ} \mathrm{C}$ on seawater temperature will increase the coverage by Menbranipora membranacea on wild kelp beds by a factor of 9 and 62, respectively. Similarly, Matsson et al. (2019) found that the coverage on M. membranacea was increased by 64 times when the average daily sea temperature increased by $0.8^{\circ} \mathrm{C}$ at a semi-offshore site compared to a fjord site in northern Norway. Interestingly, we also found that the epibionts were mainly located in the proximal part (new tissues) of the frond in June at the Rotsund site while it was the opposite at the Kraknes site with epibionts mainly in the older distal part. This could also be an effect of the different environmental parameters, such as temperature, salinity, and current in the present study. Our results also in agreement with Matsson et al. (2019) who found a large variation in the timing of the epibiont outbreak on cultivated kelp between sites which were located in a relatively small geographic area. The variation in the onset of biofouling between the two sites in the present study further highlights the importance of optimal site selection for S. latissimi aquaculture in the north of Norway.

\section{Minerals content}

The high mineral content of S. latissima (Table 2) is a factor of concern in relation to feed and food applications. Among the minerals analyzed in the present study, potassium was the most abundant followed by sodium, calcium, magnesium, and phosphorus. The present study suggests that the environmental conditions at the cultivation site may affect the minerals composition of S. latissima, and thereby, the potential use and value of the biomass (Sharma et al. 2018; Bak 2019). However, there is the possibility that different growing season may result in different minerals content of S. latissima. Our data also shows that cultivation depth has a clear effect on the analyzed mineral content of S. latissima. The phosphorus content in the present study was $1.3-4.8 \mathrm{~g} \mathrm{~kg}^{-1} \mathrm{dw}$, comparable to $S$. latisima cultivated in central Norway and Faroe Islands (Sharma et al. 2018; Bak 2019), but higher than that reported for S. latissima cultivated in Danish waters, which ranged between 1.1 and $1.3 \mathrm{~g} \mathrm{~kg}^{-1} \mathrm{dW}$ (Boderskov et al. 2021). The phosphorus content was also shown to be $40 \%$ higher at the Kraknes site than at the Rotsund site, indicating there can be significant differences between sites resulting from environmental parameters. 
Currently, there is a strong focus on iodine in S. latissima since this is the limiting factor for consumption (Blikra et al. 2021). Dietary values for recommended intake $(150 \mu \mathrm{g}$ iodine day ${ }^{-1}$ for adults) and upper intake level $(600 \mu \mathrm{g}$ iodine day $^{-1}$ for adults) have been established by the European Food Safety Authorities (EFSA 2014). Both low and high iodine levels in the diet may result in health issues such as thyroid disorders (Henjum et al. 2020). To avoid excessive iodine levels in foods containing seaweeds, a maximum iodine level of $2000 \mathrm{mg} \mathrm{kg}^{-1}$ dried seaweed products were recommended by France (CEVA 2014). In Germany, a much lower limit of $20 \mathrm{mg} \mathrm{kg}^{-1} \mathrm{dw}$ iodine in seaweed has been recommended (BfR 2007). The iodine content found in the present study was high, which is expected for $S$. latissima, and within the range of previous studies (1612-6568 mg kg${ }^{-1} \mathrm{dw}$ ) (Roleda et al. 2018; Stévant et al. 2018; Boderskov et al. 2021). However, the iodine concentration can be reduced by $38-94 \%$ by post-harvesting processing such as blanching, boiling, and fermentation, as found by Lüning and Mortensen (2015), Bruhn et al. (2019), and Nielsen et al. (2020). This has the potential to bring the iodine content below the threshold value of CEVA. In the present study, iodine content decreased with cultivation depth at both cultivation sites, and Kraknes sori had lower iodine content compared to Rotsund sori. The lowest iodine content of S. latissima was found at 0-2 $\mathrm{m}$ depth at the Rotsund site and the authors suggest this may be due to the high temperature and low salinity. This is in agreement with previous studies showing that the iodine content was lower in biomass grown in low salinity environments, due to its proposed role as an osmo-regulator in kelps (Nitschke and Stengel 2014; Lüning and Mortensen 2015). In the end, not just the iodine content in S. latissima, but also the amount of S. latissima consumed determines the total intake of iodine. When developing foods containing S. latissima, both these factors need to be considered.

\section{Potentially toxic elements}

The PTEs content in seaweed is largely species-specific and shows geographic and seasonal variation within species (Bak 2019; Roleda et al. 2019; Duinker et al. 2020). As reported by Duinker et al. (2020) who studied 27 species along the Norwegian coast and found that red and brown seaweed were higher in cadmium content than green seaweed. The average cadmium content found in the present study was between 0.63 and $2.17 \mathrm{mg} \mathrm{kg}^{-1} \mathrm{dw}$ (Table 2). This is in the range of S. latissima cultivated in Norway $\left(0.16-3.1 \mathrm{mg} \mathrm{kg}^{-1} \mathrm{dw}\right.$ ) while lower than the content in kelp cultivated in the Faroe Islands (2.26-2.50 mg kg-1 dw) (Sharma et al. 2018; Bak 2019; Roleda et al. 2019). The values obtained in the present study were below the recommended maximum cadmium content for food supplements in EU regulations of $3.0 \mathrm{mg}$ cadmium $\mathrm{kg}^{-1}$ wet weight. This corresponds to $30 \mathrm{mg}$ cadmium $\mathrm{kg}^{-1} \mathrm{dw}$ assuming that $10 \%$ of the seaweed is dry matter (OJEU L138/75 2014). In previous studies, the cadmium content of S. latissima in Norway showed clear geographical variations with higher values in the north $\left(>1.0 \mathrm{mg} \mathrm{kg}^{-1}\right.$ dw) (Duinker et al. 2020). This is in accordance with our values for kelp cultivated at Kraknes, which were between 1.5 and $2.17 \mathrm{mg} \mathrm{kg}^{-1} \mathrm{dw}$. The reason for the higher levels in the north of Norway are unknown. However, the cadmium content of kelp cultivated at Rotsund was between 0.63 and $0.96 \mathrm{mg} \mathrm{kg}^{-1} \mathrm{dw}$ in June which is below the value mentioned above and comparable to the values found in central Norway (0.436-0.9 $\mathrm{mg} \mathrm{kg}^{-1} \mathrm{dw}$ ) (Sharma et al. 2018; Roleda et al. 2019). Kleppe (2017) found that the cadmium content of both S. latissima and Alaria esculenta decreased with increasing frond length, whereas our results showed an opposite trend with higher cadmium content in larger sporophytes. In addition, the cadmium content was increased with cultivation depth and the average values at Rotsund was only $47 \%$ of that at Kraknes indicating a large variation in cadmium content between depth and site within the same geographic region.

The total arsenic content in the present study differed significantly between sites and sori origin. Our results of the total arsenic content were in the expected range of $52-91 \mathrm{mg} \mathrm{kg}^{-1} \mathrm{dw}$, which was reported by Roleda et al. (2019) for S. latissima collected from Norwegian seawaters. Roleda et al. (2019) also found a significant geographic variation between different sites that were latitudinally different (Bodø and Trondheim) in Norway. The two studies indicate the site variations of arsenic content both in geographical and regional scale in Norway. Arsenic occurs as many different chemical forms and inorganic arsenic is considered the most toxic form. Based on previous studies, we can expect that the inorganic arsenic content in S. latissima remains below $1 \%$ of the total arsenic content (Maulvault et al. 2015; Biancarosa et al. 2018; Bak 2019). With this assumption, the maximum content of inorganic arsenic $S$. latissima in the present study was $0.77 \mathrm{mg} \mathrm{kg}^{-1}$ $\mathrm{dw}$. At present, there is no recommended maximum arsenic level in seafood. According to the literature, the most successful method of arsenic reduction is soaking of dried samples followed by boiling, which removed approximately 90\% of total arsenic in Laminaria digitata and Saccharina japonica (Ownsworth et al. 2019).

Currently, the EU does not have specific regulations for maximum levels of lead in seaweeds. However, the maximum level for lead in food supplements was set at $3 \mathrm{mg}$ lead kg-1 ww, this corresponds to $30 \mathrm{mg}$ lead kg-1 $\mathrm{dw}$ if we assume that the dry matter content is $10 \%$ (OJEU L161/9 2015). The lead content of S. latissima found in the present study was far below the EU maximum content for food supplements. The mercury content at both sites was 
in the range of those previously reported for S. latissima from Norwegian seawaters (0.0009-0.081) (Duinker et al. 2020) and also from a commercial farm in Faroe Islands $\left(<0.06 \mathrm{mg} \mathrm{kg}^{-1} \mathrm{dw}\right)$ (Bak 2019). These values are below the EU maximum level for food supplements, which is $0.10 \mathrm{mg}$ mercury $\mathrm{kg}^{-1} \mathrm{ww}$ (corresponding to $3 \mathrm{mg}$ lead $\mathrm{kg}^{-1} \mathrm{dw}$ if we assume the dry matter content is $10 \%$ ) (OJEU L364/5 2014). In this regard, S. latissima biomass cultivated in the present study would be considered safe for consumption and as a source for food and feed applications, as long as excessive consumption is avoided.

\section{Conclusion}

This is the first study on the minerals and PTEs content of S. latissima cultivated in the north of Norway (in the Arctic) and the first investigation into the effect of sporeling translocation on the growth and chemical composition of the resulting S. latissima. The current study showed that the cultivation site had the strongest effect on the growth, biofouling, minerals, and PTEs content of cultivated S. latissima even within a relatively small geographical area $(90 \mathrm{~km})$, this is considered within the "local" geographic range in Norway. The site with lower seawater temperatures, higher nutrient levels, and no freshwater influence had significantly better growth (the longest average frond length recorded for S. latissima in the literature) and a much later outbreak of fouling organisms. Sori origin was found had a significant effect on the growth only at the Kraknes site with $S$. latissima produced from the Kraknes sori having better growth. The current study emphasizes the importance of site selection and selecting traits with high growth rates for seeding and cultivation in order to achieve maximum biomass in any future $S$. latissima cultivation efforts in the north of Norway. The PTEs content varied between sites and are lower than the recommended maximum level for food supplements in the EU regulations. The authors conclude that S. latissima biomass cultivated in the present study would be considered safe for consumption and as a source for food and feed applications, as long as excessive consumption is avoided. However, the presence of iodine and PTEs in seaweed products need to be monitored and it is recommended that a specific EU regulation on the maximal level of PTEs in seaweed products should be established.

Supplementary Information The online version contains supplementary material available at https://doi.org/10.1007/s10811-021-02620-y.

Acknowledgements The authors would like to thank Akavplan-Niva for use of their cultivation license, Ocean Forest for helping with sporeling production and Arne Samelsen from Lyngsskjellan AS for assistance with deployment and sampling. The also acknowledge the help of the staff at the Nofima Havbruks facility where the hatchery set up was established.

Funding Open access funding provided by Nofima the food research institute. This study was supported by the project "SUREAQUAA Nordic Centre of Excellence on Bioeconomy (grant no. 82342)" funded by NordForsk and Nofima and the project "TastyKelp (grant no. 194050)", funded by the Research Council of Norway and Nofima.

Data availability All data generated or analyzed during this study are included in this published article.

\section{Declarations}

Conflict of interest The authors declare no competing interests.

Open Access This article is licensed under a Creative Commons Attribution 4.0 International License, which permits use, sharing, adaptation, distribution and reproduction in any medium or format, as long as you give appropriate credit to the original author(s) and the source, provide a link to the Creative Commons licence, and indicate if changes were made. The images or other third party material in this article are included in the article's Creative Commons licence, unless indicated otherwise in a credit line to the material. If material is not included in the article's Creative Commons licence and your intended use is not permitted by statutory regulation or exceeds the permitted use, you will need to obtain permission directly from the copyright holder. To view a copy of this licence, visit http://creativecommons.org/licenses/by/4.0/.

\section{References}

Andersen GS, Pedersen MF, Nielsen SL (2013) Temperature acclimation and heat tolerance of photosynthesis in Norwegian Saccharina latissima (Laminariales, Phaeophyceae). J Phycol 49:689-700

Araújo R, Vázquez Calderón F, Sánchez López J, Azevedo IC, Bruhn A, Fluch S, Garcia Tasende M, Ghaderiardakani F, Ilmjärv T, Laurans M, Mac Monagail M, Mangini S, Peteiro C, Rebours C, Stefansson T, Ullmann J (2021) Current status of the algae production industry in Europe: an emerging sector of the Blue Bioeconomy. Front Mar Sci 7:626389

Augyte S, Yarish C, Redmond S, Kim JK (2017) Cultivation of a morphologically distinct strain of the sugar kelp, Saccharina latissima forma angustissima, from coastal Maine, USA, with implications for ecosystem services. J Appl Phycol 29:1967-1976

Bak UG (2019) Seaweed cultivation in the Faroe Islands: an investigation of the biochemical composition of selected macroalgal species, optimised seeding technics, and open-ocean cultivation methods from a commercial perspective. PhD Thesis, Technical University of Denmark, Kgs. Lyngby, Denmark

Bak UG, Mols-Mortensen A, Gregersen O (2018) Production method and cost of commercial-scale offshore cultivation of kelp in the Faroe Islands using multiple partial harvesting. Algal Res 33:36-47

Baker BH, Sultan SE, Lopez-Ichikawa M, Waterman R (2019) Transgenerational effects of parental light environment on progeny competitive performance and lifetime fitness. Philos Trans R Soc Lond B 374:20180182

BfR (2007) Health risks linked to high iodine levels in dried algae. BfR Opinion No. 026/2007. Bundesinstitut fur Risikobewertung, Berlin

Biancarosa I, Belghit I, Bruckner CG, Liland NS, Waagbø R, Amlund H, Heesch S, Lock E-J (2018) Chemical characterization of 21 
species of marine macroalgae common in Norwegian waters: benefits of and limitations to their potential use in food and feed. Sci Food Agric 98:2035-2042

Blikra JM, Wang X, James P, Skipnes D (2021) Saccharina latissima cultivated in Northern Norway: reduction of potentially toxic elements during processing in relation to cultivation depth. Foods 10:1290

Boderskov T, Nielsen MM, Rasmussen MB, Balsby TJS, Macleod A, Holdt SL, Sloth JJ, Bruhn A (2021) Effects of seeding method, timing and site selection on the production and quality of sugar kelp, Saccharina latissima: A Danish case study. Algal Res 53:102160

Broch OJ, Alver MO, Bekkby T, Gundersen H, Forbord S, Handå A, Skjermo J, Hancke K (2019) The kelp cultivation potential in coastal and offshore regions of Norway. Front Mar Sci 5:529

Broch OJ, Ellingsen IH, Forbord S, Wang X, Volent Z, Alver MO, Hand A, Andresen K, Slagstad D, Reitan KI, Olsen Y, Skjermo J (2013) Modelling the cultivation and bioremediation potential of the kelp Saccharina latissima in close proximity to an exposed salmon farm in Norway. Aquac Environ Interact 4:187-206

Bruhn A, Tørring DB, Thomsen M, Canal-Vergés P, Nielsen MM, Rasmussen MB, Eybye KL, Larsen MM, Balsby TJS, Petersen JK (2016) Impact of environmental conditions on biomass yield, quality, and bio-mitigation capacity of Saccharina latissima. Aquac Environ Interact 8:619-636

Bruhn A, Brynning G, Johansen A, Lindegaard MS, Sveigaard HH, Aarup B, Fonager L, Andersen LL, Rasmussen MB, Larsen MM, Elsser-Gravesen D, Børsting ME (2019) Fermentation of sugar kelp (Saccharina latissima)-effects on sensory properties, and content of minerals and metals. J Appl Phycol $31: 3175-3187$

CEVA (2014) Edible seaweed and French regulation. Synthesis made by CEVA (31/03/2014). https://www.cybercolloids.net/sites/defau 1t/files/seaweed\%20and\%20regulation2014.pdf

Chapman ARO, Markham JW, Lüning K (1978) Effects of nitrate concentration on the growth and physiology of Laminaria saccharina (Phaeophyta) in culture. J Phycol 14:195-198

Davison I, Greene R, Podolak EJ (1991) Temperature acclimation of respiration and photosynthesis in the brown alga Laminaria saccharina. Mar Biol 110:449-454

Duinker A, Kleppe M, Fjære E, Biancarosa I, Heldal HE, Dahl L, Lunestad BT (2020) Knowledge update on macroalgae food and feed safety. Rapport fra havforskningen 2020-44, 28 p. https://www.hi.no/hi/nettrapporter/rapport-fra-havforskni ngen-en-2020-44

EFSA (2014) EFSA Panel on Dietetic Products, Nutrition and Allergies (NDA). Scientific opinion on dietary reference values for iodine. EFSA J 12:3660

FAO (2020) The state of world fisheries and aquaculture: sustainability in action. FAO, Rome, pp 1-206

Forbord S (2020) Cultivation of Saccharina latissima (Phaeophyceae) in temperate marine waters: nitrogen uptake kinetics, growth characteristics and chemical composition. PhD Thesis, NTNU, Trondheim

Forbord S, Steinhovden KB, Rød KK, Handå A, Skjermo J (2018) Cultivation protocol for Saccharina latissima. In: Charrier B, Wichard T, Reddy CRK (eds) Protocols for macroalgae research. CRC Press, Boca Raton, pp 37-59

Forbord S, Matsson S, Brodahl GE, Bluhm BA, Broch OJ, Handå A, Metaxas A, Skjermo J, Steinhovden KB, Olsen Y (2020a) Latitudinal, seasonal and depth-dependent variation in growth, chemical composition and biofouling of cultivated Saccharina latissima (Phaeophyceae) along the Norwegian coast. J Appl Phycol 32:2215-2232
Forbord S, Steinhovden KB, Solvang T, Handå A, Skjermo J (2020b) Effect of seeding methods and hatchery periods on sea cultivation of Saccharina latissima (Phaeophyceae): a Norwegian case study. J Appl Phycol 32:2201-2212

Førde H, Forbord S, Handå A, Fossberg J, Arff J, Johnsen G, Reitan KI (2016) Development of bryozoan fouling on cultivated kelp (Saccharina latissima) in Norway. J Appl Phycol 28:1225-1234

Fortes MD, Lüning K (1980) Growth rates of North Sea macroalgae in relation to temperature, irradiance and photoperiod. Helgol Meeresunters 34:15-29

Futsæter G, Rueness J (1985) Metode for kontroll av livssyklus, krysningsfors $\varnothing \mathrm{k}$ og masseproduksjon av sporofytter i kultur av Laminaria saccharina (L) Lamour. Delrapport fra prosjektet Eksperimentelle unders $\emptyset$ kelser av potensielt anvendbare marine makroalger (NTNF), University of Oslo, $23 \mathrm{pp}$

Gerard VA, DuBois K, Greene R (1987) Growth responses of two Laminaria saccharina populations to environmental variation. Hydrobiologia 151:229-232

Grebe GS, Byron CJ, Gelais AS, Kotowicz DM, Olson TK (2019) An ecosystem approach to kelp aquaculture in the Americas and Europe. Aquacult Rep 15:100215

Han T, Kain JM (1996) Effect of photon irradiance and photoperiod on young sporophytes of four species of the Laminariales. Eur J Phycol 31:233-240

Henjum S, Brantsæter AL, Holvik K, Lillegaard ITL, Mangschou B, Parr CL, Starrfelt J, Stea TH, Andersen LF, Dahl LJ (2020) Benefit and risk assessment of iodization of household salt and salt used in bread and bakery products. Opinion of the Panel on Nutrition, Dietetic Products, Novel Food and Allergy of the Norwegian Scientific Committee for Food and Environment. https://www.ign. org/p142003629.html

Hurd CL (2000) Water motion, marine macroalgal physiology, and production. J Phycol 36:453-472

Jevne LS, Forbord S, Olsen Y (2020) The effect of nutrient availability and light conditions on the growth and intracellular nitrogen components of land-based cultivated Saccharina latissima (Phaeophyta). Front Mar Sci 7:557460

Kerrison PD, Stanley MS, Edwards MD, Black KD, Hughes AD (2015) The cultivation of European kelp for bioenergy: site and species selection. Biomass Bioenergy 80:229-242

Kim JK, Kraemer GP, Yarish C (2015) Use of sugar kelp aquaculture in Long Island Sound and the Bronx River Estuary for nutrient extraction. Mar Ecol Prog Ser 531:155-166

Kleppe M (2017) Kadmium, uorganisk arsen og jod i dyrket og viltvoksende butare (Alaria esculenta) og sukkertare (Saccharina latissima). Master Thesis, University of Bergen, Bergen

Krumhansl KA, Lee JM, Scheibling RE (2011) Grazing damage and encrustation by an invasive bryozoan reduce the ability of kelps to withstand breakage by waves. J Exp Mar Biol Ecol 407:12-18

Lüning K, Mortensen L (2015) European aquaculture of sugar kelp (Saccharina latissima) for food industries: iodine content and epiphytic animals as major problems. Bot Mar 58:449-455

Matsson S, Christie H, Fieler R (2019) Variation in biomass and biofouling of kelp, Saccharina latissima, cultivated in the Arctic, Norway. Aquaculture 506:445-452

Maulvault Ana L, Anacleto P, Barbosa V, Sloth JJ, Rasmussen Rie R, Tediosi A, Fernandez-Tejedor M, van den Heuvel FHM, Kotterman M, Marques A (2015) Toxic elements and speciation in seafood samples from different contaminated sites in Europe. Environ Res 143:72-81

Müller R, Laepple T, Bartsch I, Wiencke C (2009) Impact of oceanic warming on the distribution of seaweeds in polar and cold-temperate waters. Bot Mar 52:617-638

Nielsen CW, Holdt SL, Sloth JJ, Marinho GS, Sæther M, Funderud J, Rustad T (2020) Reducing the high iodine content of Saccharina 
latissima and improving the profile of other valuable compounds by water blanching. Foods 9 (5):569

Nitschke U, Stengel DB (2014) Iodine contributes to osmotic acclimatisation in the kelp Laminaria digitata (Phaeophyceae). Planta 239:521-530

OJEU L138/75 (2014) Commission Regulation (EU) No 488/2014 of 12 May 2014 amending Regulation (EC) No 1881/2006 as regards maximum levels of cadmium in foodstuffs. Off $\mathrm{J}$ Eur Union $\mathrm{L}$ 138:75-79

OJEU L364/5 (2014) Official journal of the European union L 364 , 20 december 2006, pp. 5-24. Commission Regulation (EC) No $1881 / 2006$ of 19 December 2006, setting maximum levels for certain contaminants in foodstuffs. Off J Eur Union L 364: 5-24

OJEU L161/9 (2015) Commission Regulation (EU) 2015/1005 of 25 June 2015 amending Regulation (EC) No 1881/2006 as regards maximum levels of lead in certain foodstuffs. Off J Eur Union L 161:9-13

Olafsen T, Winther U, Olsen Y, Skjermo J (2012) Value created from productive oceans in 2050 . A report prepared by a working group appointed by the Royal Norwegian Society of Sciences and Letters (DKNVS) and the Norwegian Academy of Technological Sciences (NTVA). https://www.sintef.no/contentassets/f0252 60af6b8435394eced5e03939e11/value-created-from-productiveoceans-in-2050.pdf

Ownsworth E, Selby D, Ottley CJ, Unsworth E, Raab A, Feldmann J, Sproson AD, Kuroda J, Faidutti C, Bücker P (2019) Tracing the natural and anthropogenic influence on the trace elemental chemistry of estuarine macroalgae and the implications for human consumption. Sci Total Environ 685:259-272

Pedersen MF, Borum J, Leck Fotel F (2010) Phosphorus dynamics and limitation of fast- and slow-growing temperate seaweeds in Oslofjord, Norway. Mar Ecol Prog Ser 399:103-115

Peteiro C, Sánchez N, Dueñas-Liaño C, Martínez B (2014) Open-sea cultivation by transplanting young fronds of the kelp Saccharina latissima. J Appl Phycol 26:519-528

Roleda MY, Skjermo J, Marfaing H, Jónsdóttir R, Rebours C, Gietl A, Stengel DB, Nitschke U (2018) Iodine content in bulk biomass of wild-harvested and cultivated edible seaweeds: inherent variations determine species-specific daily allowable consumption. Food Chem 254:333-339

Roleda MY, Marfaing H, Desnica N, Jónsdóttir R, Skjermo J, Rebours C, Nitschke U (2019) Variations in polyphenol and heavy metal contents of wild-harvested and cultivated seaweed bulk biomass: health risk assessment and implication for food applications. Food Control 95:121-134

Rolin C, Inkster R, Laing J, McEvoy L (2017) Regrowth and biofouling in two species of cultivated kelp in the Shetland Islands. UK J Appl Phycol 29:2351-2361

Saunders MI, Metaxas A, Filgueira R (2010) Implications of warming temperatures for population outbreaks of a nonindigenous species (Membranipora membranacea, Bryozoa) in rocky subtidal ecosystems. Limnol Oceanogr 55:1627-1642

Sharma S, Neves L, Jon F, Mydland L, Øverland M, Horn S (2018) Seasonal and depth variations in the chemical composition of cultivated Saccharina latissima. Algal Res 32:107-112

Skaar H (2019) The effect of deployment time on growth and biofouling on cultivated Sugar kelp (Saccharina latissima). Masters Thesis, University of Bergen, Bergen

Stévant P, Marfaing H, Duinker A, Fleurence J, Rustad T, Sandbakken I, Chapman A (2018) Biomass soaking treatments to reduce potentially undesirable compounds in the edible seaweeds sugar kelp (Saccharina latissima) and winged kelp (Alaria esculenta) and health risk estimation for human consumption. J Appl Phycol 30:2047-2060

Wang X, Broch OJ, Forbord S, Handå A, Skjermo J, Reitan KI, Vadstein O, Olsen Y (2014) Assimilation of inorganic nutrients from salmon (Salmo salar) farming by the macroalgae (Saccharina latissima) in an exposed coastal environment: implications for integrated multi-trophic aquaculture. J Appl Phycol 26:1869-1878

Young EB, Berges JA, Dring MJ (2009) Physiological responses of intertidal marine brown algae to nitrogen deprivation and resupply of nitrate and ammonium. Physiol Plantarum 135:400-411

Publisher's note Springer Nature remains neutral with regard to jurisdictional claims in published maps and institutional affiliations. 